\title{
STUDIES ON THE MUCOPROTEINS OF HUMAN PLASMA. I. DETERMINATION AND ISOLATION ${ }^{2}$
}

\author{
By RICHARD J. WINZLER, ARTHUR W. DEVOR, ${ }^{2}$ JOHN W. MEHL, AND \\ IRENE M. SMYTH
}

\author{
(From the Department of Biochemistry and Nutrition, University of Southern California \\ School of Medicine, Los Angeles)
}

(Received for publication February 13, 1948)

The presence in plasma of protein-like materials with properties of polypeptides or proteoses has been demonstrated repeatedly, but little has been done toward the characterization of these materiaks. The concentration of such materials in plasma rises markedly in patients with cancer or with certain other diseases, but here again little is known of the source or significance of the increased levels. The relation of these protein-like materials to the glycoproteins and mucoproteins of plasma is likewise in a state of considerable confusion.

The present series of experiments has grown out of three distinct avenues of attack (a) the demonstration, polarographically, of high molecular weight compounds containing cystine in sulfosalicylic acid filtrates of serum ( 1 to 6$),(b)$ the demonstration of polypeptide-like substances in serum deproteinated with trichloracetic acid (7 to 10 ), and $(c)$ the demonstration of a carbohydraterich protein, seromucoid, present in filtrates of serum deproteinated by heat (11 to 14 ). It appears very likely that these materials are identical, and for reasons that will be developed in this paper, the materials will be referred to as mucoproteins.

Winzler and Burk (6) isolated the non-dialyzable material from sulfosalicylic acid filtrates of rat blood, and compared the properties and occurrence of this material with the older studies of plasma polypeptides. They concluded that the isolated product was identical with the substances

\footnotetext{
1 Supported by grants from the National Research Council Committee on Growth, acting for the American Cancer Society, and from the National Advisory Cancer Council. We wish to thank the Hancock Foundation for providing facilities used in this work.

2 Some of these data are taken from a dissertation submitted by A. W. Devor to the Graduate School of the University of Southern California in partial fulfillment of the requirements for the degree of Doctor of Philosophy. Present address: North Dakota State Teachers College, Minot, N. D.
}

giving the "index of polypeptidemia" as well as the "polarographic filtrate wave." The material was classed as a proteose because it was soluble in sulfosalicylic acid, was not coagulated with heat, and was salted out with ammonium sulfate. Mayer (15) had previously isolated some of this material from sulfosalicylic acid filtrates of horse serum by precipitating it with alcohol, and called the product a "mucoidähnliche Substanz" because of the high sulfur, carbohydrate and glucosamine contents. Both in the preparations from rat blood and those from horse serum the materials were especially characterized by being very low in nitrogen and high in carbohydrate in comparison to the composition of most proteins. They resembled in this regard the seromucoid isolated from boiled serum by Zannetti (14) and subsequently studied by Bywaters (11), by Hewitt (12) and by Rimington (13).

The present work is concerned with the determination, isolation, and chemical characterization of these materials from normal human plasma, and was undertaken as part of a study of their physiological significance, especially in relation to cancer.

\section{DETERMINATION OF PLASMA MUCOPROTEINS}

The concentration of mucoprotein-like substances in plasma has been shown to increase under various pathological conditions, notably in cancer and in pyogenic infections. We have, therefore, investigated chemical methods for the determination of mucoproteins in human plasma, and are reporting our observations in the present communication.

Most of the quantitative work on the plasma mucoproteins in the past has been carried out using plasma deproteinized by means of sulfosalicylic acid or trichloracetic acid. The effectiveness of these protein precipitants, as well as of perchloric acid (16), has been investigated, the results 
showing that addition to human plasma of optimal concentrations of perchloric acid $(0.6 \mathrm{M})$ or sulfosalicylic acid ( $0.2 \mathrm{M})$ leave in the filtrate about $5 \mathrm{mg}$. of non-dialyzable nitrogen per $100 \mathrm{ml}$. of plasma, this nitrogen being largely mucoprotein in nature. The most effective level of trichloracetic acid $(0.5 \mathrm{M})$ leaves only about $0.2 \mathrm{mg}$. of nondialyzable nitrogen in the filtrate. We have accordingly selected $0.6 \mathrm{M}$ perchloric acid as the standard means of separating the plasma proteins from plasma mucoproteins. The protein-like materials in such filtrates have been determined by an adaptation of the method of Burstein (17). This has involved the addition of a strongly acid solution of phosphotungstic acid to the perchloric acid filtrate to precipitate the mucoproteins. The determination of the amount of mucoprotein in the precipitate has been carried out by determining its protein content by means of a quantitative biuret reaction (18), its carbohydrate content using the orcinol reaction (19), its tyrosine content using the phenol reagent of Folin (20), or its nitrogen content using digestion and Nesslerization.

\section{Procedure}

To $2 \mathrm{ml}$. of serum or plasma are added $8 \mathrm{ml}$. of $0.75 \mathrm{M}$ perchloric acid and the mixture shaken. In exactly ten minutes the precipitated proteins are filtered off through Whatman No. 50 filter paper. To $5 \mathrm{ml}$. of the filtrate is added $1 \mathrm{ml}$. of 5 per cent phosphotungstic acid in $2 \mathrm{~N} \mathrm{HCl}$. In 15 minutes the precipitated mucoproteins are centrifuged down and washed once with phosphotungstic acid.

The tyrosine content ${ }^{3}$ of the precipitate is determined by dissolving it in $6.5 \mathrm{ml}$. of $1 / 5$ saturated sodium carbonate, adding $1 \mathrm{ml}$. of phenol reagent and, after one hour, reading the color development with a red filter on a KlettSummerson colorimeter. A standard containing $0.05 \mathrm{mg}$. of tyrosine is similarly treated.

The carbohydrate content of the precipitate is determined after washing it with 95 per cent ethyl alcohol. The alcohol-washed precipitate is dissolved in $0.5 \mathrm{ml}$. of saturated sodium carbonate, and $1 \mathrm{ml}$. of 2 per cent orcinol in $14.3 \mathrm{~N} \mathrm{H}_{2} \mathrm{SO}_{4}$ is added followed by $7.5 \mathrm{ml}$. of $14.3 \mathrm{~N} \mathrm{H}_{2} \mathrm{SO}_{4}$. This is mixed well in a large test tube and placed in a water bath at $80^{\circ} \mathrm{C}$. for 15 minutes and then cooled in an ice bath. A blank and a standard containing $0.05 \mathrm{mg}$. of galactose and $0.05 \mathrm{mg}$. of mannose are similarly treated. The carbohydrate is then deter-

${ }^{3}$ Although the values obtained with Folin's phenol reagent are reported as "tyrosine," it is recognized that this reagent is not specific for tyrosine groups in proteins. mined from Klett-Summerson colorimeter readings using a green filter.

The protein content of the phosphotungstic acid precipitate is determined by adding $1 \mathrm{ml}$. of biuret reagent to the precipitate dissolved in $5 \mathrm{ml}$. of $1 / 5$ saturated sodium carbonate, and comparing the color with $5 \mathrm{mg}$. of serum albumin similarly treated using a Klett-Summerson colorimeter and a green filter.

The nitrogen content of the precipitate is determined by digesting it with $1 \mathrm{ml}$. of $1: 1 \mathrm{H}_{2} \mathrm{SO}_{4}$, diluting to 25 ml., and Nesslerizing a $5 \mathrm{ml}$. aliquot.

\section{Results}

Results of the investigation of a number of normal human plasmas and those from a number of patients with cancer are shown in Table I. It is seen that the levels of perchloric acid-soluble, phosphotungstic acid-insoluble tyrosine, carbohydrate, nitrogen and protein are significantly higher than normal in the cancer patients. 'A more detailed study of the relation of plasma mucoprotein levels to cancer will be the subject of another communication (21).

TABLE I

Plasma mucoprotein levels in normal and cancer patients

\begin{tabular}{|c|c|c|c|c|c|c|}
\hline & $\begin{array}{c}\text { No. } \\
\text { of } \\
\text { cases }\end{array}$ & Tyrosine* & $\begin{array}{c}\text { Carbo- } \\
\text { hydrate* }\end{array}$ & $\begin{array}{c}\text { Nitro- } \\
\text { gen* }\end{array}$ & Protein* & $\begin{array}{c}\text { Ratio } \\
\text { CHO/T }\end{array}$ \\
\hline $\begin{array}{l}\text { Normal } \\
\text { Cancert }\end{array}$ & $\begin{array}{l}10 \\
10\end{array}$ & $\begin{array}{c}\text { mg. \% } \\
3.38 \pm 0.27 \\
8.53 \pm 0.7\end{array}$ & $\begin{array}{c}m g . \% \\
12.6 \pm 1.1 \\
33.0 \pm 2.6\end{array}$ & $\begin{array}{c}m g: \% \\
5.6 \pm 0.6 \\
22.8 \pm 1.82\end{array}$ & $\begin{array}{c}\text { mg. \% } \\
86.7 \pm 9.5 \\
228 \pm 15.5\end{array}$ & $\begin{array}{c}\text { mg. \% } \\
3.69 \pm 0.23 \\
3.85 \pm 0.30\end{array}$ \\
\hline
\end{tabular}

* Including the standard error of the mean calculated from the relation

$$
S E=\sqrt{d^{2} / n-1} / \sqrt{n}
$$

where " $d$ " is the deviation from the mean and " $n$ " is the number of observations.

$\dagger$ The cancer patients were relatively advanced cases and were distributed as follows: 4, carcinoma of cervix with metastases; 3, breast carcinomas with metastases; 2, multiple myeloma; 1 , Hodgkins disease.

It is of special interest that in spite of the increased amounts of mucoprotein, the tyrosinecarbohydrate ratio of about 3.7 is not significantly different from normal in the plasma from cancer patients, and is similar to that isolated from pooled normal human plasma (see Table IV) indicating that the material present in abnormal amounts in cancer blood is similar to that occurring normally. Whether it is identical with and has the same source as that present in normal blood must be determined by further experimentation.

One of the factors affecting the determination of plasma mucoproteins by the method described 
TABLE II

Coprecipitation of mucoprotein with perchloric acid-precipitated proteins

\begin{tabular}{|c|c|c|}
\hline $\begin{array}{l}\text { Additions in final volume of } 10 \mathrm{ml} \text {. } \\
\text { of } 0.6 \mathrm{M} \text { perchloric acid }\end{array}$ & $\begin{array}{c}\text { Mucoprotein- } \\
\text { tyrosine }\end{array}$ & $\begin{array}{l}\text { Recovery of } \\
\text { mucoprotein }\end{array}$ \\
\hline $\begin{array}{l}1 \mathrm{mg} \text {. mucoprotein } * \\
140 \mathrm{mg} \text {. serum albumin } \dagger \\
1 \mathrm{mg} \text {. mucoprotein }+140 \mathrm{mg} \text {. } \\
\text { serum albumin } \\
1 \mathrm{ml} \text {. normal human plasma } \\
1 \text { mg. mucoprotein }+2 \mathrm{ml} \text {. } \\
\text { normal human plasma }\end{array}$ & $\begin{array}{l}\text { mg. in } 100 \mathrm{ml} . \\
\text { P.C.A. filtrate } \\
3.5 \\
0.04 \\
2.74 \\
\\
3.6 \\
5.9\end{array}$ & $\begin{array}{l}\text { per cent } \\
\frac{100}{78} \\
\overline{66}\end{array}$ \\
\hline
\end{tabular}

The mucoprotein, serum albumin or plasma or their combinations were made to $6 \mathrm{ml}$. with distilled water and $4 \mathrm{ml}$. of $1.5 \mathrm{M}$ perchloric acid were added. Filtration was in ten minutes. Tyrosine determinations were made on $5 \mathrm{ml}$. of the filtrate as described in the procedure.

* Mucoprotein prepared from perchloric acid filtrates of normal human plasma by $\left(\mathrm{NH}_{4}\right)_{2} \mathrm{SO}_{4}$ precipitation and having a tyrosine content of $3.5 \%$.

† Serum albumin prepared by sodium sulfate fractionation.

is the coprecipitation of mucoprotein with the proteins. A study of this coprecipitation was carried out adding to plasma or to serum albumin purified mucoprotein isolated by the method to be described, and determining the recovery in the perchloric acid filtrates. The results of this experiment are shown in Table II. It is seen that the mucoprotein is completely recovered from pure solutions, but with addition of plasma or purified serum albumin the recoveries are markedly reduced.

The apparent mucoprotein levels of plasma are also influenced by the extent of dilution of the plasma before addition of perchloric acid, the levels rising with higher dilution. This is shown in Table III. The increase in plasma mucoprotein levels with increasing dilution is undoubtedly related to the coprecipitation already mentioned.

TABLE III

\section{A pparent plasma mucoprotein levels at different plasma dilution}

ml. plasma in $10 \mathrm{ml}$. of
$0.6 \mathrm{M}$ perchloric acid
0.5
1.0
1.5
2.0
3.0
4.0
5.0

mg. mucoprotein-tyrosine per $100 \mathrm{ml}$. plasma*

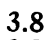

3.2

2.8

2.8

2.0

1.9

2.1

* Determined as.described under procedure.
From the experiments shown in Tables II and III, it may be estimated that the values obtained by the methods described are at least 30 per cent lower than those actually existing in the plasma. Attempts to minimize this effect by rapid centrifugation of the perchloric acid-plasma mixture have not been particularly fruitful due to the difficulty of obtaining clear supernatants.

In view of these considerations it is to be expected that the protein level of plasma should have some influence on the apparent mucoprotein level. Since many cancer patients have an associated hypoproteinemia it might be suspected that this could account for the high plasma mucoprotein levels found in cancer patients. However, little correlation has been found between the total plasma protein and mucoprotein levels in normal individuals and cancer patients. Therefore, while the protein content of the plasma is undoubtedly a factor affecting the plasma mucoprotein determination, it cannot account for the difference between normal and pathological bloods.

Because of the ease of determination of the tyrosine content of the mucoproteins we have preferred to carry out the major part of our work with this procedure. It has been also our practice to check the tyrosine results frequently by simultaneous carbohydrate determination since this serves as a means of identifying the phosphotungstic acid precipitate as mucoprotein.

\section{ISOLATION OF MUCOPROTEINS}

The most extensive studies on the quantitative occurrence in normal and pathological plasma of the type of material under consideration have been made using filtrates of plasma or serum deproteinated with trichloracetic or sulfosalicylic acids. Our initial isolations have been therefore made using such protein-free filtrates. Evidence will be presented in other communications showing that these materials are not liberated from proteins under the action of the high acidity of the precipitating reagents, and that they are present in untreated plasma. Isolation of the materials has also been achieved by means of ammonium sulfate fractionation without use of acid precipitants or heat.

Most preparations were isolated from $0.6 \mathrm{M}$ perchloric acid filtrates of plasma since it was 
found that this concentration left a minimal amount of protein-bound tyrosine and of nondialyzable nitrogen in the filtrate.

\section{Procedure}

To remove the proteins, $500 \mathrm{ml}$. of plasma were diluted with an equal volume of water, and $500 \mathrm{ml}$. of $1.8 \mathrm{M}$ perchloric acid or of $0.6 \mathrm{M}$ sulfosalicylic acid were added while stirring. Filtration through Whatman No. 5 filter paper was started within two to five minutes after protein precipitation. The filtrate was dialyzed nearly free of acid, and the mucoproteins were precipitated by saturating the dialysate with ammonium sulfate at a $\mathrm{pH}$ of 4 . The materials were exhaustively dialyzed against distilled water and dried by lyophilization. Approximately $20 \mathrm{mg}$. of the product were isolated per $100 \mathrm{ml}$. of plasma by this procedure.

\section{Results}

The product was a white, fluffy, somewhat hygroscopic material, which dissolved easily in water forming a slightly turbid solution. It gave positive reactions in the usual protein and amino acid tests and also showed a very strong Molisch reaction.

A number of samples isolated by the procedure outlined have been examined using the electrophoretic technique. The results of a typical preparation obtained at $\mathrm{pHs}$ of 8.3 and 4.5 are shown in Figure 1. It is seen that the preparation shows at least three electrophoretically demonstrable components. All three of these components have isoelectric points that are much lower than the

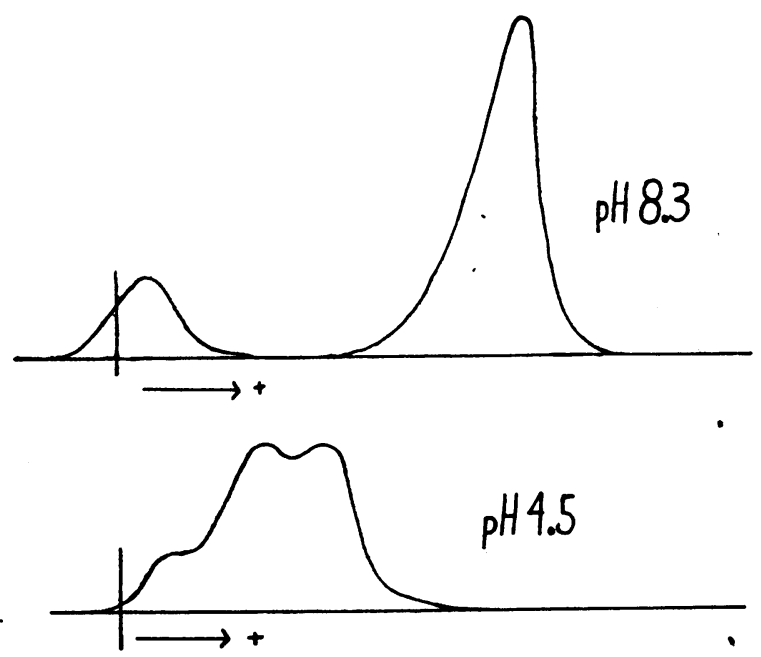

Fig. 1. Electrophoretic Patterns of Mucoproteins Isolated BY the Perchloric ACId Method plasma proteins. More complete data on the electrophoretic characterization of the mucoproteins will be presented in a later communication. The low isoelectric points observed suggested that with the proper selection of $\mathrm{pH}$ and plasma concentrations, mucoproteins might be demonstrable in untreated plasma. This was tried following the suggestion of Dr. M. P. Peterman (22) who has observed in the plasma of patients with gastric cancer a small amount of an electrophoretic component which moved toward the positive electrode at a $\mathrm{pH}$ of 4 . We have also observed this component at $\mathrm{pH} 4.5$ in a number of patients in whom the plasma mucoprotein levels were elevated. This component has been isolated electrophoretically and characterized chemically, and seems to correspond to one of the plasma mucoproteins observed in our isolated preparations. This problem is under investigation at the present time.

\section{CHEMICAL COMPOSITION}

The chemical composition of the materials isolated from pooled normal human plasma insofar as it has been investigated, is tabulated in grams per 100 grams of moisture-free material in Table IV. These studies must be regarded as preliminary because a mixture of components, frequently present in different proportions, is involved. More

TABLE IV

Chemical composition of normal human plasma mucoproteins

\begin{tabular}{|c|c|c|}
\hline Component & Method & $\underset{\text { gm. }}{\operatorname{gm} . / 100}$ \\
\hline $\begin{array}{l}\text { Ash } \\
\text { Nitrogen } \\
\text { Amino nitrogen } \\
\quad \text { (per cent of } \\
\text { total N) }\end{array}$ & $\begin{array}{l}\text { Ignition in air } \\
\text { Digestion and Nesslerization } \\
\text { Van Slyke nitrous acid method }\end{array}$ & $\begin{array}{l}2.8 \\
7.9 \\
4.3\end{array}$ \\
\hline $\begin{array}{l}\text { Protein } \\
\text { Carbohydrate }\end{array}$ & $\begin{array}{l}\text { Biuret method (18) } \\
\text { Orcinol reaction (as mannose- } \\
\text { galactose) (19) }\end{array}$ & $\begin{array}{l}58.0 \\
15.1\end{array}$ \\
\hline $\begin{array}{l}\text { Hexosamine } \\
\text { Hexuronic acid } \\
\text { Lipid } \\
\text { Cholesterol } \\
\text { Phosphorus } \\
\text { Sulfur } \\
\text { Cystine } \\
\text { Methionine } \\
\text { Tyrosine } \\
\text { Tryptophane }\end{array}$ & $\begin{array}{l}\text { Acetylacetone method (13) } \\
\text { Carbazole method (23) } \\
\text { Hot alcohol extraction } \\
\text { Liebermann-Burchard reaction } \\
\text { Molibdivanidate method (24) } \\
\text { Gravimetric } \\
\text { Polarographic (25) } \\
\text { McCarthy-Sullivan method (26) } \\
\text { Phenol reagent (20) } \\
\text { Erlich reagent (27) }\end{array}$ & $\begin{array}{l}11.9 \\
\text { neg. } \\
12.9 \\
\text { neg. } \\
0.064 \\
1.3 \\
0.5 \\
2.1 \\
4.2 \\
1.8\end{array}$ \\
\hline
\end{tabular}

* Average of ten preparations.

† On moisture-free basis. 
detailed chemical studies will await separation of - the individual components.

Nitrogen. In these studies, as in those on materials similarly isolated from rat blood and from horse serum, the nitrogen content was very low. Winzler and Burk (6) advanced the hypothesis that the low nitrogen content of their rat blood "proteose" was due to its combination with the sulfosalicylic acid used to remove the plasma proteins. This was based in part on the very high sulfur content of the material. A correction of the nitrogen content to a "sulfosalicylic acid-free" basis brought the nitrogen up to usual protein values. This hypothesis must now be abandoned, since it has been shown that the chemical composition of material isolated from sulfosalicylic acid filtrates and from perchloric acid filtrates is the same, and in neither case indicates the presence of the precipitant. The low nitrogen content of the isolated material must be explained on the basis of its high carbohydrate and hexosamine content as suggested by Mayer (15) for a similar material isolated from horse serum, and in addition on the basis of the high lipid content demonstrated in the present work.

The low nitrogen closely corresponds to the low "protein" content of the material as measured by the quantitative biuret method of Mehl (18). The absorption spectrum of the biuret reaction product given by the mucoprotein shows an absorption peak at $550 \mathrm{~m} \mu$, the same as that obtained with a sample of human serum albumin, and suggests a relatively high molecular weight of the mucoproteins.

Seromucoid preparations isolated by various investigators have had nitrogen contents ranging between 7.1 and 13.6 per cent, depending upon the source of the material and the methods of preparation. The nitrogen content of seromucoid preparations have in general varied inversely with their carbohydrate content.

Carbohydrate. The carbohydrate content of the material isolated from human plasma was determined using the orcinol method of Sörenson and Haugaard (19) as well as by a method utilizing the Molisch reaction. Both of these reactions give colors with hexose but not hexosamine, and results with these two methods agreed quite well. Hexosamine was determined by the procedure described by Rimington (13) using acetylacetone and Erlich's reagent. Tests for hexuronic acids were made by the carbazole method of Dische (23).

It is seen from Table IV that the carbohydrate content is in the neighborhood of 15 per cent based on a galactose-mannose standard. This is somewhat lower than that reported by Mayer (15), but higher than that reported by Winzler and Burk (6) for similar preparations. It lies in the range of the values given for different preparations of seromucoid.

Indication that the carbohydrate is a hexose is afforded by the fact that Tauber's pentose test gave negative results, and that the absorption curve obtained in the Molisch $\alpha$-naphthol reaction corresponded to that obtained with hexoses rather than to that of pentoses. The color developed in the orcinol test for carbohydrates varies with different carbohydrates, mannose and glucose giving less color than galactose. This makes it essential to know the identity of the carbohydrates determined before accurate determination of the amount present can be made. An indication that the carbohydrate is a mixture of galactose and mannose is afforded by the observation that the ratio of readings obtained in the orcinol reaction at 420 and $540 \mathrm{~m} \mu$ with the KlettSummerson colorimeter corresponded more nearly to a mixture of galactose and mannose than to either alone. Usually this ratio was such as to indicate a relative excess of galactose over mannose. Galactose is known to be present, since mucic acid was isolated from a preparation treated with concentrated nitric acid. The presence of a fermentable sugar was also demonstrated using Schizosaccharomyces pombe. These observations are in general accord with those of Seibert $e t$ al. $(28,29)$ as well as those of Hewitt (12) and Rimington (13).

In agreement with the observations of Mayer (15) with material isolated from horse serum, of Zanetti (14), Bywaters (11), and Rimington (13) with seromucoid, and of Hewitt (12) with globoglycoid, Table IV shows that our materials have contained considerable amounts of hexosamine. No isolation or identification of this amino sugar from the material isolated from human plasma has been attempted. In view of the identification of glucosamine in horse seromucoid (30), however, it seems likely that the amino sugar present in our preparations is glucosamine. 
Hexuronic acids were not present in amounts detectable by the method of Dische (23).

It is clear that the overall analysis of the carbohydrate and hexosamine content of the material isolated in this work places it into the group of mucoproteins according to the classification of Meyer (31), since they contain more than 4 per cent hexosamine. It cannot, of course, be concluded that each component in the mixture contains this same high carbohydrate content. However, in view of the paralleling low isoelectric points, heat stabilities, and solubilities, we have tentatively assumed that all three components are mucoproteins.

In the purest preparations of the seromucoid of Rimington (13), the ratio of hexose to hexosamine was very close to $2: 1$. Since the mucoprotein prepared in the present work is a mixture of at least three components, an integral ratio is scarcely to be expected. It is of interest, however, that this ratio has usually been much closer to $1: 1$ than to $2: 1$ in our preparations. This relation must be reexamined when the components are isolated in pure form.

Lipids. Winzler and Burk (6) reported that lipids were absent in their rat blood "proteose," using ether-extractable material as a criterion of lipid content. Ether has also failed to extract lipids from human plasma mucoprotein. When the mucoprotein isolated from fresh plasma was extracted with hot alcohol in a Soxhlet apparatus, however, considerable alcohol-soluble material was extracted. Preparations isolated from older plasma samples contained considerably less lipid than fresh samples. The white, waxy alcoholsoluble residue was readily soluble in ether or benzene, but not in water. It gave a negative Liebermann-Burchard test for cholesterol, and contained approximately 1.1 per cent nitrogen, 1.1 per cent carbohydrate (orcinol test) and 0.32 per cent phosphorus, the composition varying somewhat in different preparations. All the phosphorus present in the mucoprotein was extracted with hot alcohol.

Sulfur. The sulfur content of the mucoproteins isolated from rat blood (5.8 per cent [6]), from horse serum (3.7 per cent [15]) and from fresh human plasma ( 1.3 per cent) is greater than can be accounted for on the basis of the sulfur in cystine and methionine. It was found that after mild acid hydrolysis of the mucoproteins isolated from fresh human plasma, a precipitate could be obtained by treating the hydrolysate with barium chloride, indicating the presence of easily hydrolyzable sulfuric acid. One of the most striking differences in the composition of mucoproteins from the rat, the horse and the human lies in the sulfur content. Whether this represents the result of differences in the methods of preparation or real species differences is as yet not clear.

Studies on the amino acid composition of the mucoprotein are as yet too incomplete to have such significance.

\section{DISCUSSION}

The data reported indicate the presence of at least three protein components which have the chemical composition and physicochemical properties that distinguish them from other plasma proteins. The chemical data must be regarded as preliminary since a mixture of proteins has been studied. It is felt that the evidence supports the thesis that all three components are mucoproteins. Evidence to be reported in other communications indicates that the same or similar mucoproteins are present in increased amounts in the plasma of patients with a number of diseases, including many types of cancer, pneumonia, and tuberculosis. That the plasma concentration of similar or perhaps identical materials increases in diseases of different etiology suggests that there is a metabolic abnormality common to all. Studies on the source and physiological significance of the plasma mucoproteins should be of considerable value in testing this hypothesis.

There can be little doubt that the total serum polysaccharides studied by Seibert and her collaborators $(28,29)$ include the mucoproteins described here. Their total serum polysaccharide levels lay in the neighborhood of $100 \mathrm{mg}$. per cent in the normal individual, this value rising to as high as 150 or more in patients with cancer or tuberculosis. The normal plasma mucoprotein level expressed in terms of carbohydrate is 14.4 $\pm 3.2 \mathrm{mg}$. per cent and may rise to $75 \mathrm{mg}$. per cent in cancer patients. Whether or not the increase in total serum polysaccharide in pathological blood observed by Seibert is entirely due to increase in plasma mucoproteins cannot yet be ascertained, although the similarity in the absolute increase in 
carbohydrate suggests that this may be the case. It is unlikely that the conjugated amino acids studied in tungstic acid filtrates of plasma by Christiensen and Lynch (32) have any relation to the mucoproteins studied here, since the mucoproteins are precipitated by this reagent. There is some question as to whether the conjugated amino acids in plasma deproteinized with 2.5 per cent trichloracetic acid contain mucoproteins, since we have found that this concentration of trichloracetic acid is just under that required for optimal precipitation of plasma proteins, and that it leaves in solution small amounts of relatively high carbohydrate-containing proteins.

\section{SUMMARY}

Methods for the determination of the mucoprotein content of normal and pathological human plasma have been developed. Plasma from cancer patients contains higher than normal amounts of mucoprotein.

A mixture of mucoproteins has been isolated by saturating perchloric acid filtrates of normal human plasma with ammonium sulfate at $\mathrm{pH} 4$. Electrophoretic studies indicate the presence of three components all with low isoelectric points. The material is high in carbohydrate, hexosamine and sulfur, and low in nitrogen content in comparison to other proteins.

\section{BIBLIOGRAPHY}

1. Albers, D., Nachprüfung der polarographischen Präger Krebs-Reaktion. Biochem. Ztschr., 1940, 306, 236.

2. Brdicka, R., Novak, F. V., and Klumpar, J., Critical examination of the polarographic test for cancer in deproteinated sera. Acta radiol. et cancerol. bohem. et morav., 1939, $2,27$.

3. Muller, O. H., and Davis, J. S., Polarographic studies of proteins and their degradation products. II. Normal values of the "Protein Index." Arch. Biochem., 1947, 15, 39.

4. Schmidt, H. W., Erfahrungen zur polarographischen Krebsdiagnose im enteiweissten Serum. Ztschr. f. Krebsforsch., 1940, 50, 390.

5. Waldschmidt-Leitz, E., and Mayer, K., Erfahrungen zur polarographischen Krebsdiagnose. Ztschr. f. Physiol. Chem., 1939, 261, 1.

6. Winzler, R. J., and Burk, D., Blood proteose and cancer. J. Nat. Cancer Inst., 1944, 4, 417.

7. Cristol, P., and Puech, A., $\AA$ propos de l'indice de désamination. Signification de l'indice de polypeptidemie et de l'indice de désamination. Bull. et mém. Soc. med. d. hôp. de Paris, 1926, 50, 1828.
8. Goiffon, R., and Spaey, J., Mésure de l'index-tyrosine des polypeptides sériques. Bull. Soc. chim. biol., 1934, 16, 1675.

9. Hahn, A., Der Doppelstickstoff, ein Diagnostikum für endogenen Eiweisszerfall, insebesonders für okkulte eitrige Prozesse. Biochem. Ztschr., 1921, 121, 262.

10. Wolff, E., Sur l'albumosemie a l'état physiologique et pathologique. Ann. de med., 1921, 10, 185.

11. Bywaters, H. W., Uber Seromucoid. Biochem. Ztschr., 1909, 15, 322.

12. Hewitt, L. F., Separation of serum albumin into two fractions. II. Observations on the nature of the glycoprotein fraction. Biochem. J., 1937, 31, 360.

13. Rimington, C., Seromucoid and the bound carbohydrate of the serum proteins. Biochem. J., 1940, 34, 931.

14. Zannetti, C. U., Sull' ovimucoide e sopra un nuovo glicoproteide contenuto nel siero di sangue. Ann. di chim. e di farm., 1897, 26, 529.

Sull' ovimucoide e siero-mucoide. Gazz. chim. ital., 1903, 33, 160.

15. Mayer, K., Über eine Mucoidähnliche Substanz aus Serum. Ztschr. f. physiol. Chem., 1942, 275, 16.

16. Neuberg, C., Strauss, E., and Lipkin, L. E., Convenient method for deproteinization. Arch. Biochem., 1944, 4, 101.

17. Burstein, M., Quelques variations expérimentales de la polypeptidemie chez le chien. J. de physiol. et de path. Gén., 1937, 35, 71.

18. Mehl, J. W., The biuret reaction of proteins in the presence of ethylene glycol. J. Biol. Chem., 1945, 157, 173.

19. Sorenson, M., and Haugaard, G., Uber die Anwendbarkeit der Orcinreaktion zur Bestimmung der Art and Menge von Kohlenhydratgruppen in Eiweissstoffen. Biochem. Ztschr., 1933, 260, 247.

20. Folin, O., and Ciocalteu, V., On tyrosine and tryptophane determinations in proteins. J. Biol. Chem., 1927, 73, 627.

21. Winzler, R. J., and Smyth, I., Studies on the mucoproteins of human plasma. II. Plasma mucoprotein levels in cancer patients. J. Clin. Invest., 1948, 27, 617.

22. Peterman, M. P., Karnofsky, D. A., and Hogness, K. R., Electrophoretic studies on the plasma proteins of patients with neoplastic disease. II. An acid protein present in the plasma. Cancer, 1948, $1,104$.

23. Dische, Z., A new specific color reaction of hexuronic acids. J. Biol. Chem., 1947, 167, 189.

24. Simonsen, D. G., Wertman, M., Westover, L. M., and Mehl, J. W., The determination of serum phosphate by the molybdivanadate method. J. Biol. Chem., 1946, 166, 747.

25. Stern, A., Beach, E. F., and Macy, I. G., Polarographic microdetermination of cystine in protein hydrolysates. J. Biol. Chem., 1939, 130, 733. 
26. McCarthy, T. E., and Sullivan, M. X., A new and highly specific colorimetric test for methionine. J. Biol. Chem., 1941, 141, 871.

27. Milone, H. S., and Everitt, E. L., Estimation of tryptophane content of various proteins. Proc. Soc. Exper. Biol. \& Med., 1942, 51, 82.

28. Seibert, F. B., and Atno, A. J., Determination of polysaccharide in serum. J. Biol. Chem., 1946, $163,511$.

29. Seibert, F. B., Seibert, M. V., Atno, A. J., and Campbell, H. W., Variation in protein and polysaccharide content of sera in the chronic diseases, tuberculosis, sarcoidosis and carcinoma. J. Clin. Invest., 1947, 26, 90.

30. Rimington, $C$., The isolation of a carbohydrate derivative from serum-proteins. Biochem. J., 1929, 23, 430.

31. Meyer, K., Mucoids and glycoproteins. Adv. in Protein Chem., 1945, 2, 249.

32. Christensen, H. N., and Lynch, E. L., The conjugated, non-protein amino acids of plasma. I. Postabsorptive concentrations of human plasma, serum, and erythrocytes. J. Biol. Chem., 1946, 163, 741.

II. A study of deproteinizing techniques. J. Biol. Chem., 1946, 166, 87. 